\title{
Polimastia Axilar: Um Diagnóstico no Puerpério
}

\author{
Axillary Polymastia: A Postpartum Diagnosis
}

Cátia LOURENÇO ${ }^{1}$, Margarida BRANDÃO²

Acta Med Port 2014 Mar-Apr;27(2):274-274

Palavras-chave: Axila/anomalias congénitas; Mama/anomalias congénitas; Período Pós-Parto.

Keywords: Axilla/abnormalities; Breast/abnormalities; Postpartum Period.

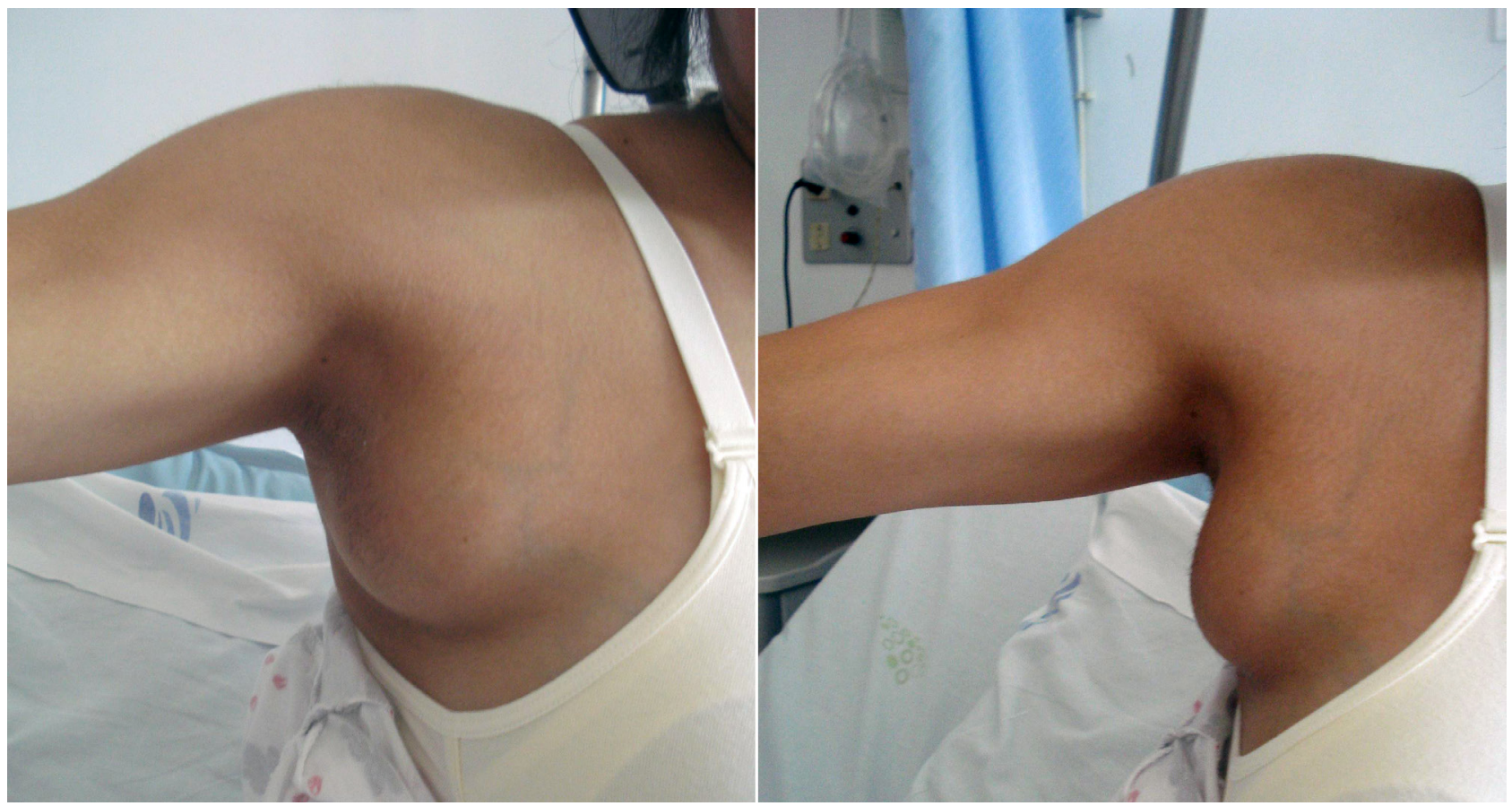

Figure 1 - Tecido mamário acessório na axila

Primigesta com 30 anos, saudável, com gestação de 39 semanas $+1 \mathrm{~d}$, que decorreu sem intercorrências.

Realizada cesariana electiva por feto em apresentação pélvica em primigesta, tendo sido observado um útero bicórneo durante a cirurgia.

No primeiro dia de pós-operatório a puérpera referiu a presença de tumefacções axilares. Ao exame foram observadas tumefacções axilares bilaterais com cerca de $5 \mathrm{~cm}$, indolores (Fig. 1), compatíveis com a presença de tecido mamário acessório (polimastia).
O tecido mamário acessório está presente na altura do nascimento em $1 \%$ da população. A polimastia refere-se à presença de qualquer tipo de tecido mamário acessório, sendo a axila o local mais frequente de aparecimento. Alguns estudos sugeriram uma associação com alterações renais, pelo que a ecografia renal pode estar indicada nestas doentes. A indicação para realização de ecografia reno-vesical neste caso é reforçada pelo facto de haver uma malformação mülleriana associada. A puérpera efectuou ecografia reno-vesical que não revelou alterações.

\section{REFERÊNCIAS}

1. Amaranathan A, Balaguruswamy K, Bhat RV, Bora MK. An ectopic breast tissue presenting with fibroadenoma in axilla. Arch Pediatr. 2010;17:1162-4.

2. Patel PP, Ibrahim AM, Zhang J, Nguyen JT, Lin SJ, Lee BT. Accessory breast tissue. Eplasty. 2012;12:ic5.

3. Mukhopadhyay M, Saha AK, Sarkar A. Fibroadenoma of the ectopic breast of the axilla. Indian J Surg. 2010;72:143-5. 


\section{Polimastia Axilar: Um Diagnóstico no Puerpério Acta Med Port 2014:27:274-274}

Publicado pela Acta Médica Portuguesa, a Revista Científica da Ordem dos Médicos

Av. Almirante Gago Coutinho, 151

1749-084 Lisboa, Portugal.

Tel: +351218428 215

E-mail: submissao@actamedicaportuguesa.com

www.actamedicaportuguesa.com

ISSN:0870-399X | e-ISSN: 1646-0758

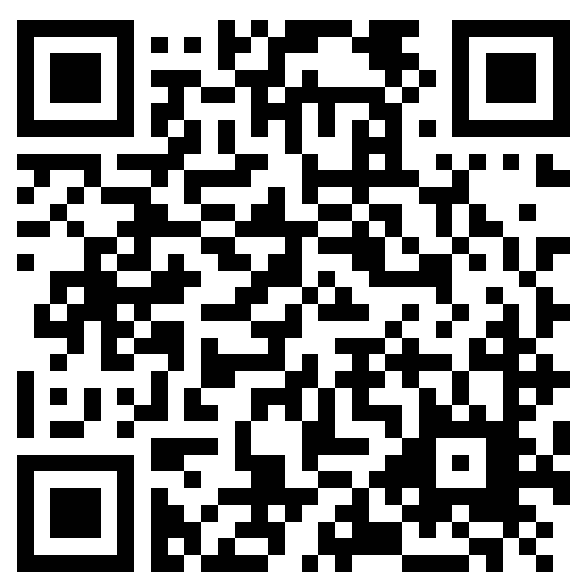

